\title{
Erratum to: "European Civil Service in (Times of) Crisis: A Political Sociology of the Changing Power of Eurocrats"
}

\section{Didier Georgakakis}

\section{Erratum to:}

D. Georgakakis, European Civil Service in (Times of) Crisis, Palgrave Studies in European Political Sociology, https://doi.org/10.1007/978-3-319-51792-6

The Publisher regrets that the below mentioned copyright text was not mentioned in the book.

This research was conducted within the framework of the high-quality laboratory for research (Labex)Tepsis of the School for Advanced Studies in the Social Sciences (École des hautes études en sciences sociales EHESS), reference number ANR-11-LABX-0067.

The online version of the original can be found under https://doi.org/10.1007/978-3-319-51792-6

(C) The Author(s) 2017

D. Georgakakis, European Civil Service in (Times of) Crisis,

Palgrave Studies in European Political Sociology,

DOI 10.1007/978-3-319-51792-6_10 